\title{
What Does Pseudo Religion Steal From Traditional Religion Psychologically
}

\author{
ZHANG Yu-ding, TAN Yu-xin, LIU Qi-zhen \\ Hubei University, Wuhan, China
}

\begin{abstract}
The pseudo religion is widely criticized for its theft and manipulation of dogmata and jargon concepts in orthodox religion to pretend to be orthodox religion and to deceive the public. However it is still in the air to expose its specific content, tactics and purpose stolen and tampered psychologically. This paper discusses the importance of establishment and development of pseudo religion through stealing religious mental concepts in traditional religion including "God", "Heaven", "Hell”, "Soul immortality", "Morality" and "Religious feeling", and studies its tricks for theft and manipulation, distortion and ultimate purposes. This paper aims at showing people the evil of pseudo religion and integrity of traditional religion.
\end{abstract}

Keywords: "God", "Morality”, "Religious feeling”, "Cosmology"

\section{Introduction}

In mainland China, the government refers "pseudo religion" to those organizations which are cult groups or destructive cults in international community and accuses them of stealing and tampering dogmata of orthodox religion to pretend to be orthodox religion in the name of orthodox religion and qigong; it is not region virtually but deceives the public in the name of orthodox religious and qigong in order to control fooled people mentally, and to establish, enlarge and develop illegal organizations in its group harming society and families. Based on this judgment, the Chinese Government always holds a zero tolerance attitude to organizations called "pseudo religion", such as "Yiguandao" at the beginning of foundation of this country, and "Falun Gong", "Eastern Lightning Cult" and "Mentuhui" several years later, determines to ban them legally and punishes their leaders and the main organizers. A consensus is reached among mainland scholars and the government about the understanding of pseudo religion, and international scholars also basically hold the same view (CHEN, 2010, p. 102) that the pseudo religion is indeed the fake religion which is in the name of and covered with religions, and that it is moon-calf appearing in the development of religion and bring catastrophe to society; "it is the most serious challenge faced by China's ruling party since its inception and its harm is worse than unemployment, inflation and corruption" (KANG, 2002). It is a tumor in modern society and a big public hazard in international community, so they agree with government's measures for banning and combat.

ZHANG Yu-ding, Lecturer, Department of Psychology of Hubei University.

TAN Yu-xin, master degree candidate, Department of Psychology of Hubei University.

LIU Qi-zhen, corresponding author, Professor, Department of Psychology of Hubei University. 
The main parts of mainland religious circles are Christianity, Catholicism, Buddhism, Islam and Taoism, and because holding their religions are divine and non-blasphemous, they are naturally sensitive and exclusive to any illegal using, distortion, tampering, boasting, holding a flag or signboard of their religions, and extremely hate treacherous behaviors of pseudo religion. Min Zhiting, president of Chinese Taoist Association says that the association shall organize Taoist associations in the country, Taoist temples and believers to indicate our integrity to the pseudo religion and eliminate evils, however, regrettably, no matter the government, scholars or the religious communities, what they expose and accuse is the fact that they only list titles of pseudo religions which illegally use traditional religions, and which steal temper terms in traditional religions like "karma", "body", "reincarnation", "original sin", "salvation", "soul" and "morality", and they fail to expose the evil purposes of stealing and mean tricks for tampering psychologically; only these are exposed, the stealing and deceive nature of pseudo religion can be exploded and it is able to prove that the false reasoning and heresy are an outcome of stealing and tampering dogmata of traditional regions; meanwhile, it will make the public understand that the false reasoning of pseudo religion is so evil that people turn up nose at it and reasons making believers obsessed: psychologically, point of view, the reason people believe religions including pseudo religion and even are pious is that psychological changes occur in this process; for instance, the needs in consciousness or subconscious levels are met; they have a certain religious experience and even mysterious experience; religious feelings occur; they find answers through religions to things and phenomena beyond explanation before; they find the ultimate fate of life. Although the pseudo religion is not religion for Chinese government and most scholars, an indisputable fact is that its believers view it as a religion. The psychological process is same for pseudo believers of pseudo religions and those of traditional religions in the process of belief.

The authors clearly know that the paper is incapable of fully discussing pseudo religions' theft, distortion and tampering in flag titles, dogmata, terms and names of traditional religions, and based on the fact that people's belief to religions is a psychological activity in fact, the paper here studies several problems related to religious psychology.

\section{The “God” Concept Stolen by Pseudo Religion From Traditional Religions}

The Religious Psychology research shows that it is religion in the history of mankind which firstly defines supernatural power as "God" and worship. It is a substitutive characteristic for all religions to believe and adore the God. Before religions, the primitive human beings only realize great pressure and important value of nature on them. On the one hand, natural things and natural forces appear as opposites or forces of alienation to people which threat people with natural disasters like floods, beasts, plagues and earthquakes, making them incapable of resisting them. Natural mysteries like wind, rain, thunder and light are used to confuse people, which bring great pressure to primitive mankind. On the other hand, natural things appear as great gifts to mankind as they bring people with natural resources including sun, air, mountains, lands, water and fire, animals and plants, and offer necessary conditions for survival and reproduction like food, clothing, clothes, accommodation and activities. This wins favor of mankind who infinitely admire it. Facing this reality, the primitive people regard natural things, natural power and mysterious using as supernatural mysterious force, respect and fear it and think the only thing they can do is obedience rather than violation. They have no idea about where this mysterious power comes from, so their obedience and reverence are blind. It is religion (or founders of religions) which firstly proposes that this 
mysterious power rests with God who creates the world, that everything is in the charge of God who arranges wind and cloud to appear and master life, death, gentle and simple lives in the world, and that the God is so powerful that he is everywhere and never makes a mistake. It is by this way that both God and religion come to the world, and the God is created by original religions in mankind history.

All pseudo religions steal the "God" concept from religions, and once this is used by pseudo religions, they will tamper and distort it as well as bring a qualitative change; the God and the extraordinary power are used by pseudo religions to threat and control believers.

What traditional religions believe is Gods in heaven, or the late founders of religions honored as "Gods" by followers who are an unreal spiritual entity, exist as a spirit god and are a symbolic symbol belief. While after the theft of pseudo religions, the Gods are tampered and replaced with living leaders of religions. In traditional religions, the founders regard unrealistic spiritual entities rather than themselves as leaders, for example, Judaism regards Jehovah as Lord and the Christianity regards Jesus as its Lord (when living, Jesus regards his religion as Judaism instead of one different from Judaism. It is his followers who truly honor his religion as Judaism, while Jesus has passed away, and he is regarded as the God with human body, the son of God, a Christ and a spiritual entity). Correspondingly, religions extremely emphasize the difference between man and god, and the difference is so large that the living people fail to reach and to dare they are Gods. In traditional religions, becoming God or immortal is a goal pursued by believers, an ultimate desire which only can be true when one is "dead", "Nirvana" or "going to heaven" instead of in real world. However, leaders of pseudo religions always claim that they are the living Gods, the "reincarnation of Jesus" and are "Lords of the universe." It is easy to see that pseudo religions are fake religions which steal, temper and distort the God concept in traditional religions, and are covered with the religious coat to pretend to be religions.

Jim Jones, the leader of "The Peoples Temple" is a living guy who claims himself "God", the "Father" and “Lord” of believers; あさはらしょうこう, the leader of Japanese Aum Doomsday Cult says he is the "Savior" of mankind; Ji Sanbao, leader of "Mentuhui" claims him the "Christ set by God"; Li Hongzhi claims that he is the "Powerful Lord" in universe and is "the king of kings".

Leaders of all pseudo religions claim themselves Gods with the purpose of consolidating the belief foundation. However, their "God" concept is stolen, plagiarized and replaced from that in traditional religions, so an indisputable fact is that the concept of "God" is created by traditional religions where God is used to explain origin of superman strength and to make people believe greatness, holy, irresistibility of Gods but obedience and worship, while Gods in pseudo religions are stolen by leaders from traditional religions and they focus on its utility. They completely tamper the meanings of God at the beginning of theft, and recklessly pretend to be "God", "Savior", "Lord Buddha", "King of kings", and claim they are Gods.

\section{The "Religious Feelings" Stolen by Pseudo Religions From Traditional Religions}

\section{“Religious Feelings” Serving as Emotional Experience of People to Existed Gods}

People are emotional animals, and boast of complex emotions. Religious feelings refer an emotional experience related to divinities of believers after understanding dogmata of religions, participating in religious activities and experiencing a solemn religious atmosphere. Specifically, this experience is an outcome that believers regard their beliefs and worship as supernatural gods, and after experiencing activities above and 
atmosphere, they naturally respect, attach, adore, worship and appreciate Gods in the heart. The emotion occurs on the basis of belief of God and religious belief, and is a manifestation of religious consciousness of believers, a reflection of religious consciousness in emotion and affection and is an inner feeling or direct experience of believers to divinities. The expression ways of religious emotions are mainly the sense of fear, dependence, gratitude, guilt, shame, peace, satisfaction, a limited sense of ego and an infinite sense to Gods. These emotions may be positive and active, such as praise, admiration, gratitude and others; they also may be negative and passive, such as fear, dependence, evil and others. The sense of awe and a sense of dependence account for a large proportion in religious feelings, which can be said two basic factors in religious feelings are essential affection foundation of religious belief.

\section{The Core and Fundamental Role of Religious Feelings in Religious Belief}

Because the objects of religious belief - the God is mystery, intangible, unknowable and unacquainted and is a supernatural object existing in the world of "opposite bank", as well as is a "transcendental" existence free of experience verification, human understanding and overall practice system, religious belief is an irrational belief, which means that religion belief and its sacredness cannot be obtained by reason but by personal emotional experience; so the religious feelings play a core and fundamental role in forming, consolidating and deepening religious beliefs. In other words, religious feelings determine the establishment, communication and consolidation. It is also because of this, the pseudo religions are interested in stealing religious feelings for their purposes.

\section{Religious Feelings Produced and Experienced by Mankind in Traditional Religions}

People having experienced major natural disasters will state with affection that we are small in front of nature, and our power, no matter in physical, intelligence or life is limited, so people regard the death arrival as arrival of "infinite" which means a greater power dominates people's life. What opposite to individual's limitation is the infinite dominating us which is viewed infinite physically, mentally and in live; it is still unknown for primitive humans before religion about where this infinite alien power comes from and who holds this power.

Living in ferocious natural environment, the primitive mankind have to face strong earthquakes, huge volcanic eruption, raging floods and beasts haunting, which severely threats their survival and security and makes them afraid and helpless. Meanwhile, because of unaccountable natural phenomena and mentality including moving mountains and roaring tsunami, earth shattering, thunder and lightning, eclipse and falling stars, four seasons changing, life and death, dreams and mental illness, they completely trust to luck and are manipulated by environment and destiny, as Hegel once said: the ignorant are not free, because what he faces is a strange world. They feel fear as a result of ignorance and strange, and death is the biggest fear in numerous senses of fear of mankind. The fear that human faces as a whole is not temporary, accidental and individual, but is frequent, repetitive, omnipresent and endless. This fear is still here even in technologically developed today: Humans face the death danger when large meteors hit the earth like dinosaurs; they face the death danger with earth. This fear for life danger is an instinct deeply rooted in human subconscious, and it comes from need that any life needs to be protected. Psychologically, it shows from "metal mother" experiment of lactating monkeys that fear causes insufficient security, which will lead life entity to seek for protection and result in a sense of dependence to reduce or eliminate fear. 
Harlow and Suomi, American psychologists (1970) perform an attachment experiment with young monkey. They separate young monkeys and the mother monkey, and then conduct a man-made "mother" for other two young monkeys, among them, one is made by bare metal wire, called "metal mother", while the other is made by foam rubber and plush clothes to which young monkeys can attach, so it is called "velvet mother." Feeders are placed on two "mothers" to specially nurse the young monkeys. Generally speaking, young monkeys suck breast to two "mothers" randomly, and if young monkeys suddenly make a terrible sound when sucking the "metal mother", they will immediately leave the her and run to the "velvet mother" and lean close to her; if they make a terrible sound when sucking the "velvet mother", instead of leaving her, young monkeys will clean much closely to her (Hilgard, 1987, p. 122). This suggests that creatures seek dependence and protection when encountering horrific and dangerous situations. This is especially true for human beings, the advanced life.

However, who can protect primitive mankind surrounded by dangers and assist them in eliminating fear and obtaining the sense of security? What can they depend on? Here hides the opportunity that people need Gods. Gods will occur and people awe and depend on them due to fear and limited strength, and it is under such a background that religion comes into being which firstly creates a supernatural God, leads people's sense of limitation, fear, attachment, appreciation and the sense of awe to divinities and then protects early jittery mankind in the name of God, eliminates their fear, making them obtain security by bowing at the foot of Gods and worshiping Gods. In a word, it is the traditional religions allowing people to produce and experience religious feelings.

\section{“Religious Feelings” of Religions Stolen and Tampered by Pseudo Religions}

Leaders in pseudo religions learn about that people tend to produce, awe and depend on Gods as well as seek for their protection out of fear and limited strength, and that religious feelings play a core and fundamental role in forming and deepening religious belief, establishing, communicating and consolidating religions, so they determine to establish and develop pseudo religions organization by borrowing the power of Gods, steal religious feelings and whoop them up, and recruit believers in virtue of religious feelings to develop pseudo religion organizations. A practice for pseudo religions is: on the one hand, knowing "there is no atheist in the trenches", they intend to create terror and claim the earth explosion, the destruction of mankind and the doomsday in order to make people fear subconsciously and to seek protection of Gods; on the other hand they take this opportunity to claim and promise that they are Gods, and much powerful than Gods, that only they can save mankind and that they can protect its believers via magical functions and supernatural power so as to trigger security and dependency needs of believers.

Leaders of pseudo religions hype "the doomsday, earth devastation and horrifying remarks like many people will die and $60 \%$ of people will die on planet within two years." People can avoid such catastrophe only they are honored as kings.

The Henotheism also hypes the doomsday, the arrival of locusts, floods, fires and other disasters, claims all people die in 1999, the doomsday in world, no one in farm and houses, and states people will be safe when he is the leader of Henotheism.

School of Sanbanpuren claims the doomsday, earth destruction and declares that "seven disasters will occur before 2000 and the doomsday is coming, that Jesus proposes those believing Lord to go to heaven, or those will go to hell", and that people can go to heaven after death when believe them. 
"Round of the door" leader Xu Chengjiang declared that "now the earth is the devil rule, the end of the robbery will come, only to join the round of the door to escape from the catastrophe."

Xue Chengjiang, the leader of "Yuandunfamen" interprets out of context of Vajra Cchedikā Prajñā Pāramitā and claims that "mappo period predicated by Sakyamuni shall be true here", that he is born to combat disasters, that he is born as leader and that he comes down to earth every 5,000 years to save the living. After spreading rumors, leaders in pseudo religions pretend to be protectors to attract believers. It can be seen from these that how pseudo religions and leaders serve their governance by stealing religious feelings like the sense of fear, attachment, gratitude and sense of infinite to Gods in traditional religions.

\section{Religious Concepts Including “Heaven”, “Hell” and “Soul Immortality” Stolen by Pseudo Religions}

A study of archaeology and anthropology to clan and tribes living in the most primitive stages in the world, such as the Kubu tribe in the Indonesian Sumatran jungle, the barbarians living on isla grande de island in the southern tip of South America, Vedda in Sri Lanka and Xilang people in India shows that they have no idea about "world of living", "world of death", "heaven", "hell", "pre-set", "later-ages", "third reincarnation", "karma", "soul immortality" and "ghost", let alone any God worship and religious activities. This shows that the early human have no idea about religions psychologically and they have no congenital characteristics to Gods and religious belief which is the production of social life; mankind is small, fragile and helplessness in front of natural forces.

However, these are the "genes" of God worship and religion belief; these religious concepts are established in the course of long religious development and deeply rooted in subconscious of nations in world after the spreading for thousands of years and of course, they are utilized and engraved in the minds of leaders of pseudo religions. These concepts are absorbed by pseudo religions and they have hastily proclaimed these things in their own fallacies, becoming a tool helping pseudo religions capture believers and control them mentally:

Henotheism, a pseudo religion organization asks believers to donate money in name of contribution and "impending ill fortune" and "donating to heaven and using in disasters" in order to raise funds for activities and meet the extravagant life of leaders when developing believers, and what they do is money fraudulence. They spread the slogan that "money and grain are dangerous in hoses unless they are in heaven as disasters are coming".

"South China Church", a branch of "Full-scope Church", a pseudo religion has once illegally set up "Heaven Bank" in Hubei, and they spread rumors everywhere that "fights will occur in the country and your money will be valueless if it is in banks instead of in "Heaven Bank" "People who do not put money in the "Heaven Bank" are not loyal to the Lord". They force believers to put money in so called "Heaven Bank" through measures like intimidation and deception with the amount reaching several million yuan.

The "Mentuhui", a pseudo religion organization hypes that "the year 1999 will see the devastation of earth as well as doomsday" and that "people believing religion will go to heaven or will go to hell."

Obviously, separating from some concepts including "world of living", "world of death", "heaven", "hell", "pre-set", "later-ages", "third reincarnation", "karma", "soul immortality" and "ghost", the theories of pseudo religions may encounter difficulties in forming and believers will not be easily captured and controlled by them. 


\section{Cosmology Stolen by Pseudo Religion From Traditional Religions}

The cosmology varies from pseudo religions to pseudo religions and for instance, the "Heaven Gate" holds that human lives outside the earth, and there is a higher world which is the "Heaven Gate", a higher spiritual realm and "their world" thought by believers, that is, the paradise in their hearts. Believers in this pseudo religion think comet is ominous, its presence means that earth will explode and mankind will be ruined. They think aliens in sci-fi stories and the UFO which has been repeatedly mistaken really exists and think that there is UFO of aliens behind AlanHale to take them back to "their world". So when the comet occurs, a time label that they wait for the spacecraft arrival to bring them back to "their world", 39 believers commit suicide collectively under the guidance of cosmology.

A pseudo religion domestically claims that: Sakyamuni also talks about tri-sa ${ }^{\wedge}$ hasra-maha ${ }^{\wedge}-\mathrm{sa}^{\wedge}$ hasra-loka-dha ${ }^{\wedge}$ tu. He says in our universe, this galaxy, there are three thousand stars like humans, which is the tampering to Buddhist cosmology. Actually, it is not true meaning of "tri-sa^hasra-maha^-sa`hasra-loka-dha^tu" in Buddhism. Chapter 18 of Dirghagama-sutra, the Buddhist scriptures declares that: with Sumeru as center and Cakravadaparvata as outline, the four-world shined by surrounding flowing light of same sun and moon is a small world (solar system), and one thousand small-world refer "Xiaoqian Shijie"; a thousand "Xiaoqian Shijie" are called "dvi-sahasra-madhyama-loka-dhatu"; one thousand "dvi-sahasra-madhyama-loka-dhatu" are "tri-sa^hasra-maha^-sa^hasra-loka-dha^tu" which include small, middle, big and three large worlds collectively known as "tri-sa^hasra-maha^-sa^hasra-loka-dha^tu". Buddhism believes that "the universe is composed of numerous 'three thousand tri-sa`hasra-maha ${ }^{\wedge}$-sa $a^{\wedge}$ hasra-loka-dha^tu’, which is immeasurable boundless; this cosmology contains rational elements of the endless universe. This pseudo religion holds that universe is made up of over 2.7 billion galaxies, and this universe is surrounded by shells. However there are universes beyond this one. 'There are over 3,000 universes in a certain scope... covered by shells which constitutes the third level of universe.' Earth is not the only living planet in this universe, and it has more than one life; there are earths in places where the current earth lies in. Former earths may be ruined or explode." People face devastation in explosion because "human is deadly evil."

Psychologically, the ultimate goal is to develop believers and drive fish in deep water in order to establish belief space for many believers. Firstly, the reason why he creates 3,000 universes is to create a space for Falun Gong realm, which means to build a "fish pond." So he concludes that: "masters have their own heavens, such as Sakyamuni, Amitabha and Mahāvairocana; these masters have their own realms. There are over 100 worlds in our galaxy"; secondly, the reason why he claims the human is deadly evil and the earth will explode is to make more people believe his theories and, in other word, to collect money from others.

\section{Conclusion}

To sum up, this article starts with the fact that religion is a kind of mental activity, and reveals the concrete manifestation of the pseudo religions' stealing, tampering and exploiting traditional religions' content. First, pseudo religons have stolen the concept of "God" from traditional religions. In the traditional religions, "God" is the spiritual entity which represents supernatural power and superhuman power, but pseudo religions replace it into a living hierarch in the world. Second, pseudo religions have stolen the "religious feeling" from traditional 
religions. The leaders of pseudo religions have seen the core and fundamental role of religious feelings in the formation and deepening of religious belief, thus using "religious feeling" to gather believers and developing pseudo religion organizations.Third, pseudo religions have stolen some religious ideas such as "Heaven", "Hell" and "Soul Immortality", to establish their own fallacies, and to bewitch and control the believers. Fourth, the pseudo religions have stolen the concept of "morality" from Taoism, distorted it, and fooled the believers with it. Fifth, pseudo religions have stolen and distorted the "cosmology" of traditional religions, misled the believers to believe in the wrong view of the universe, and built space for the development of pseudo religion organizations.

We believe that these findings would help people correctly distinguish between pseudo religions and traditional religions, recognize the essence of pseudo religions, thereby physical and mental harm. At the same time, these findings also have important theoretical and practical significance for the government to manage the pseudo religions' harm to the society.

\section{References}

CHEN, Z. M., \& ZHANG, X. L. (2001). The truth of pseudo religions. Beijing: Contemporary World Press.

CHEN, Q. P. (2010). Mind control theory. Beijing: People's Education Press.

Chinese Buddhist Association. (2001). An open letter from the Chinese Buddhist Association to the Buddhist community in China.

Religions in China, (2), 25.

Hilgard, E. R. (1987). Introduction to psychology. (X. G. ZHOU, Trans.). Beijing: Peking University Press.

KANG, X. G. (2002). The political effects of the Falun Gong issue. China Education and Society, 35(1), 5-14.

Meadow, M. J., \& Kahoe, R. D. (1988). Religious psychology. Chengdu: Sichuan People's Press. 